\title{
Heavy metals in aerosols over the seas of the Russian Arctic
}

\author{
V. Shevchenko ${ }^{\mathrm{a}, *}$, A. Lisitzin ${ }^{\mathrm{a}}$, A. Vinogradova ${ }^{\mathrm{b}}$, R. Stein ${ }^{\mathrm{c}}$ \\ ${ }^{a}$ P.P. Shirshov Institute of Oceanology, Russian Academy of Sciences, 36, Nakhimovsky Prospekt, 117997, Moscow, Russia \\ ${ }^{\mathrm{b}}$ Oboukhov Institute of Atmospheric Physics, Russian Academy of Sciences, 3, Pyzhevsky Pereulok, 119017, Moscow, Russia \\ ${ }^{\mathrm{c}}$ Alfred Wegener Institute for Polar and Marine Research, Columbusstrasse, 27568, Bremerhaven, Germany
}

Received 12 April 2002; accepted 27 September 2002

\begin{abstract}
A review of the data on heavy metals in aerosols over the seas of the Russian Arctic is presented. Results of heavy metal studies in aerosols obtained during 11 research expeditions in summer/autumn period from 1991 to 2000, and at Severnaya Zemlya and Wrangel Island in spring, in 1985-1989 are discussed. Concentrations of most heavy metals in the atmosphere in the marine boundary layer in the Russian Arctic are nearly of the same order as literature data from other Arctic areas. The content of heavy metals in the aerosols over the seas of the Russian Arctic shows an annual variation with maximal concentrations during the winter/spring season. In the summer/autumn period increased concentrations of heavy metals could be explained, in most cases, by natural processes (generation of sea salt aerosols, etc.). In some cases, aerosols from Norilsk and Kola Peninsula were detected. Particular attention was paid to estimation of horizontal and vertical fluxes of atmospheric heavy metals. We estimated annual variations in long-range transport of heavy metals into the Russian Arctic in 1986-1995. In winter and spring, up to 50\% of the average air pollutant concentrations in the Russian Arctic are due to the Arctic atmospheric pollution itself. Moreover, the monthly and annual averaged fluxes of six anthropogenic chemical elements (arsenic, nickel, lead, vanadium, zinc and cadmium) onto the surface in the Arctic were estimated, and the values obtained were in reasonable agreement with the literature data available.
\end{abstract}

(c) 2002 Elsevier Science B.V. All rights reserved.

Keywords: Aerosols; Arctic; Heavy metals; Long-range transport

\section{Introduction}

The rapid movement of air makes it an important pathway for delivering heavy metals and other contaminants to the Arctic. The atmosphere is the fastest and most direct route from the source of pollution: transport from the sources to the Arctic occurs in a matter of days or weeks (Pfirman et al., 1995; AMAP, 1997; Macdonald et al., 2000).

\footnotetext{
*Corresponding author.
}

Numerous studies have shown that aerosols in the Arctic are important for atmospheric chemistry and climate (Rahn, 1981; Barrie, 1986, 1996; Pacyna, 1991; Leck et al., 1996; Sirois and Barrie, 1999; Bigg and Leck, 2001). There is much evidence that atmospheric inputs contribute significantly to the chemical budget of marine areas (Duce et al., 1991; Lisitzin, 1996), but in the Arctic their role is underestimated.

Up to now, aerosols have been studied only to a limited extent in the Russian sector of the Arctic. 
Measurements of the elemental composition of Arctic aerosols have been conducted in the northern part of continental Siberia, on Wrangel Island, the Severnaya Zemlya Archipelago, Franz Josef Land (Rovinsky et al., 1995; Vinogradova and Polissar, 1995; Vinogradova, 1996; Koutsenogii et al., 1998, 2000; Smirnov et al., 1998). We began aerosol research in the marine boundary layer over the seas of the Russian Arctic in 1991; some results have been published elsewhere (Shevchenko et al., 1995, 1999a,b,c, 2000; Golubeva and Shevchenko, 1999). The aim of this paper is to provide a review of the data on heavy metals in aerosols over the seas of the Russian Arctic and to compare with other studies in the circumpolar Arctic.

\section{Materials and methods}

The aerosols in the marine boundary layer over the seas of the Russian Arctic were studied in 1991-2000 in 11 expeditions (Shevchenko et al., 2000).

For a comprehensive study of the amount and composition of aerosols we used complementary and overlapping methods: air filtering through specialized filters and the collection of large amounts of aerosols by nylon mesh using static electric charges. To exclude contamination from the ship, sampling was interrupted when the relative wind direction was not opposite to the ship movement. No samples were collected during rain and snowfall events.

Air was filtered through AFA-KhA-20 acetatecellulose filters with a working surface of $20 \mathrm{~cm}^{2}$ and Whatman-41 cellulose fiber filters, which trap also submicron particles $(>0.5 \mu \mathrm{m})$, including particles of sea salt. Fifty-three samples were collected by filtration, and these samples were mostly used for studying elemental composition. Blank filters were treated similarly with sample filters, except the air was passed through for only $1 \mathrm{~min}$. For most elements, blank correction was less than $10 \%$.

The amount of the aerosol material collected by the filters was insufficient for studying the mineral composition and in addition, the material itself was clogged with sea salt. Therefore, filtering was accompanied by sampling the aerosol with nylon meshes. This method allows collection of large amounts of aerosols (Chester and Johnson, 1971; Leinen et al., 1994). After the exposure (usually for 1 day) the meshes were cleaned in distilled water, the charge was removed, and the waterinsoluble particles were separated from the water by filtering through a Nucleopore filters with the pore size of $0.45 \mu \mathrm{m}$. Sampling sites for the mesh samples are shown in Fig. 1. A total of 68 samples were collected by this method.

The primary method for studying the chemical composition of aerosols was instrumental neutronactivation analysis (INAA). One hundred and twenty-one samples were analyzed by this method. The INAA procedures were similar to those described by Smakhtin et al. (1991). In preparation for the INAA, the samples and standards $(\mathrm{KH}, \mathrm{ST}$, SGT, FFA, Rus-1) were irradiated in the heat channel of the nuclear reactor of Moscow Institute of Engineering Physics (neutron flux $=2.8 \times 10^{13}$ neutrons $\mathrm{cm}^{-2} \mathrm{~s}^{-1}$ ) for $15-20 \mathrm{~h}$. We used the following standards: BCR-1 (USA), BEN (France), KH, ST-1, SGD-1a, TB, SDO-1, and GM (Russia). After irradiation the activity of samples was measured three times by germanium detectors with 4096-channel high-resolution pulse analyzers (LP-4900, Nokia, Finland and NUC8192, FMG, Hungary) in the analytical laboratory of Vernadsky Institute of Geochemistry and Analytical Chemistry, Moscow. This analytical laboratory is certified by the State Standard Committee of Russia.

$\mathrm{Mn}, \mathrm{Co}, \mathrm{Cu}, \mathrm{Zn}, \mathrm{Cd}$ and $\mathrm{Pb}$ were determined in 10 samples by atomic absorption spectroscopy (AAS) using a Perkin-Elmer 3030 equipped with a graphite furnace (located at Institute of Marine Biochemistry, Montrouge, France). Analyses were performed in a clean laboratory (class-100, US norms). The particulate metals were measured after a complete acid digestion with $\mathrm{HNO}_{3}-\mathrm{HF}-$ $\mathrm{HClO}_{4}$ at $130-140{ }^{\circ} \mathrm{C}$ in a closed Teflon system employing Suprapure acids. All analytical results were checked using the standard reference material MESS-1 from the National Research Council of 


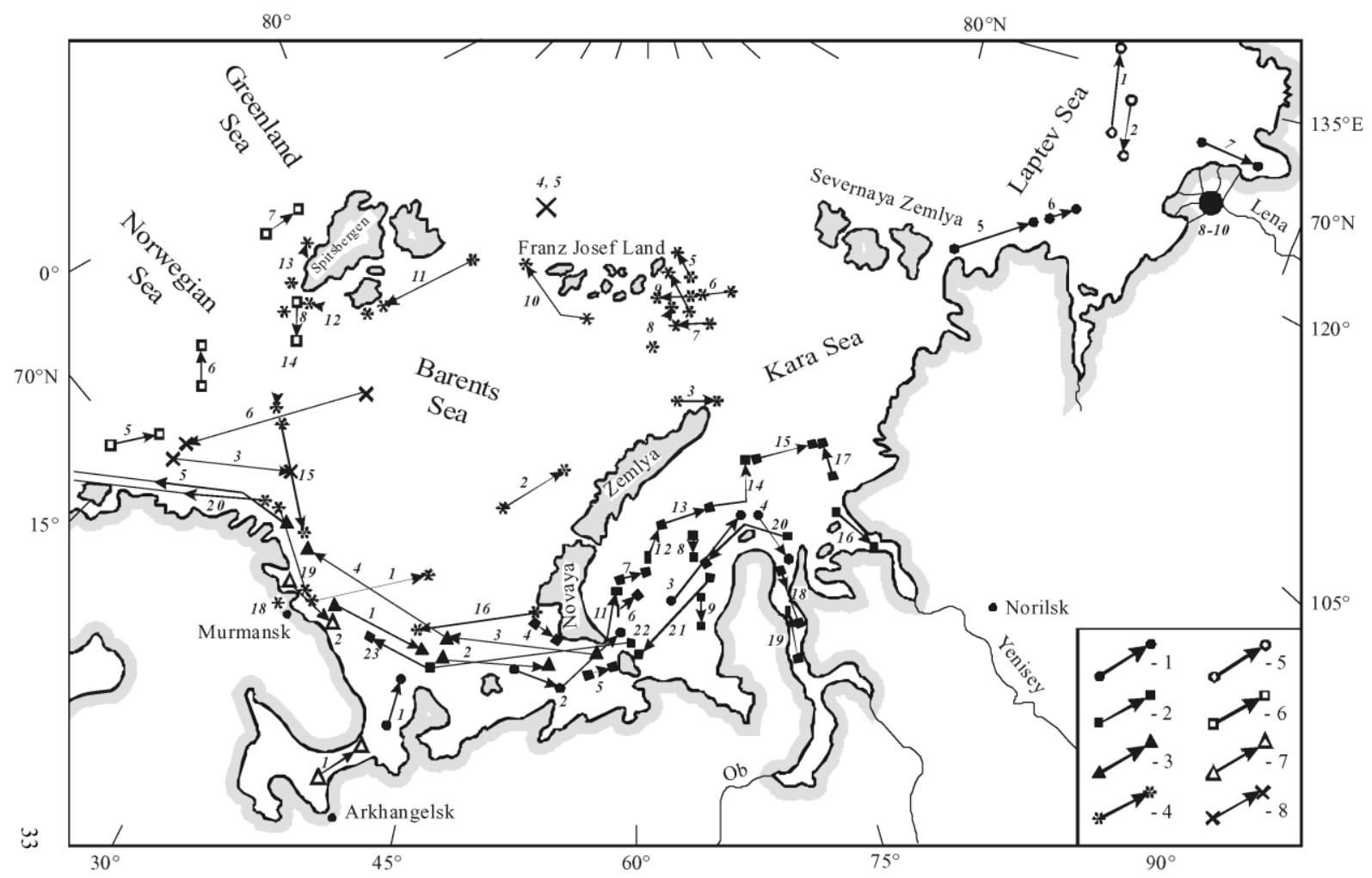

Fig. 1. Samples of aerosols collected by nylon meshes in the Arctic: SPASIBA-91 expedition (1), the 49th expedition of the research vessel (RV) Dmitrii Mendeleev (2), the 31st expedition of the RV Akademik Mstislav Keldysh (3), the 9th expedition of the RV Professor Logachev (4), ARK-XI/1 expedition of the RV Polarstern (5), the 15th expedition of the RV Professor Logachev (6), the 11th expedition of the RV Akademik Sergey Vavilov (7), and the 14th expedition of the RV Akademik Fyodorov (8) (Shevchenko et al., 2000).

Canada. Analytical precision was $5 \%$ for $\mathrm{Cu}, 6 \%$ for $\mathrm{Mn}$ and $\mathrm{Co}, 8 \%$ for $\mathrm{Zn}, 10 \%$ for $\mathrm{Cd}$ and $\mathrm{Pb}$.

Some individual aerosol particles were examined with the JXA-733 microprobe (Japan) and with a SEM-515 scanning electron microscope supplemented with a EDAX PV9900 X-ray microanalyzer (Philips, USA), located at the Alfred Wegener Institute of Polar and Marine Research (Bremerhaven, Germany) (Shevchenko et al., 1999a,b, 2000).

The possible sources of aerosols and the pathways of aerosol transport to the Arctic were revealed by analyzing meteorological maps and by calculating back trajectories of air transport to the observation points (Vinogradova, 2000).

\section{Results and discussion}

\subsection{Distribution of heavy metals in aerosols}

Heavy metals in aerosols were studied in seas of the Russian Arctic in summer and autumn expeditions (July-October) onboard the Russian research vessels and German ice-breaker Polarstern (Shevchenko et al., 1995, 1999a,b,c, 2000). Experimental data for spring elemental concentrations in the surface atmosphere in the Russian Arctic were obtained from three sampling campaigns at Severnaya Zemlya (1985, 1986 and 1988) (Vinogradova and Polissar, 1995), five campaigns at Wrangel Island (1985-1989) (Vinogra- 
dova et al., 1988; Vinogradova, 1996), and at the station 'North Pole-28' in spring 1987 (Vinogradova, 1996).

\subsubsection{Chemical composition of individual aerosol particles}

The elemental composition of individual aerosol particles in the samples collected by nylon meshes during the SPASIBA-91 expedition was studied with an X-ray microanalyzer at the Chemical Department of the Antwerp University (Shevchenko et al., 1995, 1999a).

Biogenic particles and black carbon have no major X-ray intensity, therefore, only the particles emitting X-ray radiation in response to e-beam bombardment were analyzed in the automatic mode. After the data were processed statistically, four main types of particles were recognized in the Arctic aerosol: (1) alumosilicate, (2) quartz, (3) $\mathrm{Si}-\mathrm{Fe}-$ or $\mathrm{Fe}-\mathrm{Si}$-enriched particles, and (4) combustion spheres (carbon-less ash) enriched in $\mathrm{Fe}, \mathrm{P}, \mathrm{Ni}$ and some heavy metals.

Alumosilicate and quartz particles can be considered as soil particles transported by wind. The variations of the aluminosilicate and quartz content in the samples are likely connected with variability of soil composition.

The combustion spheres enriched in $\mathrm{Fe}, \mathrm{P}, \mathrm{Cl}$, and heavy metals had the sizes from 0.3 to $3 \mu \mathrm{m}$. The combustion spheres enriched in $\mathrm{Fe}, \mathrm{Ni}, \mathrm{Cu}$, $\mathrm{Cr}, \mathrm{Zn}, \mathrm{Ca}, \mathrm{Mn}$ and $\mathrm{Sb}$ were detected by manually controlling the microanalyzer. Fig. 2 shows the characteristic X-ray spectra of combustion spheres from the Arctic aerosols. The highest concentration of the combustion spheres enriched in heavy metals was noticed in sample 6 taken from the air mass originating from the Norilsk region.

The qualitative elemental analysis of individual aerosol particles collected on Nylon meshes in the Laptev Sea in late July of 1995 (ARK XI/I trip of the ice-breaker Polarstern) and in the Kara and Barents Seas in September-early October of 1993 (the 49th expedition of the RV Dmitrii Mendeleev) was performed by scanning electron microscopy supplemented with X-ray microanalysis (Shevchenko et al., 1999b, 2000). The composition of 110 combustion spheres with diameters from 1 to $10 \mu \mathrm{m}$ varied from region to region. They mainly

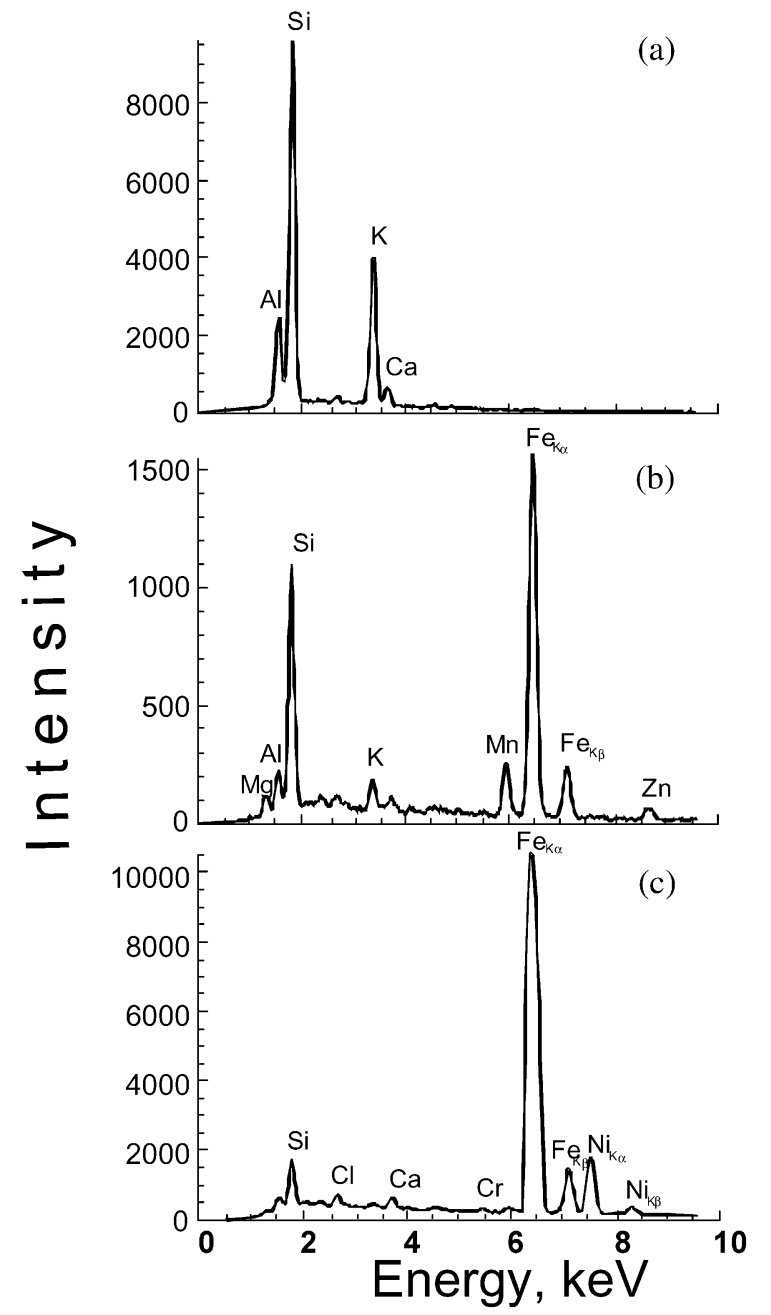

Fig. 2. X-Ray spectra of insoluble aerosol particles collected by meshes in SPASIBA-91 expedition (microprobe analysis was carried out in the Antwerpen University, Belgium): angular aluminosilicate particle (sample 6 , particle size of $5 \mu \mathrm{m}$ ) (a), combustion spheres [sample 1, diameter of $0.7 \mu \mathrm{m}$ (b), sample 6, diameter of $0.5 \mu \mathrm{m}$ (c)] (Shevchenko et al., 1999a, 2000).

consisted of $\mathrm{Si}, \mathrm{AI}, \mathrm{K}, \mathrm{Fe}$ and $\mathrm{Mg}$ in the Laptev $\mathrm{Sea} ; \mathrm{Si}, \mathrm{Al}, \mathrm{Fe}$ and $\mathrm{K}$ in the central part of the Kara $\mathrm{Sea} ; \mathrm{Fe}, \mathrm{Ni}, \mathrm{Si}$ and $\mathrm{Cu}$ in the southern Kara Sea (transport of aerosol from Norilsk); $\mathrm{Si}, \mathrm{Al}, \mathrm{Fe}$ and $\mathrm{Ni}$ in the southern Barents Sea (influence of industrial enterprises of the Kola Peninsula).

Thus, the study of the elemental composition of individual insoluble aerosol particles in the surface 
Table 1

Mean content of Sc and heavy metals in insoluble aerosols in the marine boundary layer in the Russian Arctic in summer ( $\mu \mathrm{g} / \mathrm{g}$ dry wt.)

\begin{tabular}{|c|c|c|c|c|c|c|}
\hline Element & $n^{\mathrm{a}}$ & $\begin{array}{l}\text { Arithmetic } \\
\text { mean }\end{array}$ & $\begin{array}{l}\text { Standard } \\
\text { deviation }\end{array}$ & $\begin{array}{l}\text { Geometric } \\
\text { mean }\end{array}$ & Crust $^{\mathrm{b}}$ & DM- $49-16^{\mathrm{c}}$ \\
\hline $\mathrm{Sc}$ & 48 & 4.4 & 3.1 & 3.5 & 22 & 9.2 \\
\hline $\mathrm{Cr}$ & 42 & 288 & 114 & 260 & 100 & 220 \\
\hline $\mathrm{Mn}$ & 10 & 210 & 72 & 200 & 950 & \\
\hline $\mathrm{Fe}$ & 45 & 30000 & 18200 & 25600 & 56300 & 99400 \\
\hline $\mathrm{Co}$ & 46 & 23.7 & 33 & 12.1 & 25 & 720 \\
\hline $\mathrm{Ni}$ & 36 & 311 & 677 & 57.3 & 75 & 13100 \\
\hline $\mathrm{Cu}$ & 26 & 204 & 101 & 173 & 55 & - \\
\hline $\mathrm{Zn}$ & 43 & 1115 & 777 & 833 & 70 & 1250 \\
\hline As & 17 & 7.2 & 4.2 & 5.7 & 1.8 & 32 \\
\hline $\mathrm{Pb}$ & 10 & 900 & 324 & 834 & 12.5 & - \\
\hline
\end{tabular}

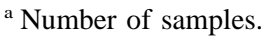

${ }^{\mathrm{b}}$ Abundance of elements in the crust after Taylor (1964).

' DM-49-16, 49th expedition of the RV 'Dmitry Mendeleev', sample 16 (Shevchenko et al., 2000).

atmospheric layer over the Arctic seas with the electron microanalyzer showed that the inorganic portion of the aerosol consists mostly of mineral particles (predominantly, quartz and alumosilicate) of land soils. Almost all the samples contained small amounts of anthropogenic ash particles enriched in $\mathrm{Fe}, \mathrm{Ni}, \mathrm{Cu}, \mathrm{Cr}, \mathrm{Zn}, \mathrm{Ca}, \mathrm{Mn}$ and $\mathrm{Sb}$. The content of ash particles in aerosols was a marker of industrial sources in the regions of Norilsk and the Kola Peninsula.

\subsubsection{Heavy metals in the insoluble fraction of aerosols}

Organic and soot carbon is of primary importance in the arctic aerosol sampled on Nylon meshes. Its content varies from 7.54 to $48.9 \%$ (Shevchenko et al., 2000) or 14-97\% expressed on an organic matter (OM) basis. The mean content of $\mathrm{C}_{\text {org }}$ was $30.2 \pm 12.5 \%$ ( \pm standard deviation); this amounted to approximately $60 \%$ of the OM. The content of heavy metals and other chemical elements in the insoluble fraction of aerosols varied very widely (Shevchenko et al., 1999a,b,c, 2000). Table 1 presents average content of Sc and heavy metals in insoluble aerosols of the Russian Arctic and the data for sample number 16 collected on September 18, 1993, in the 49th expedition of the RV Dmitrii Mendeleev. The content of many heavy metals is maximal in this sample. This anomalous sample was collected in the Yenisei
Gulf (see Fig. 1) during a strong $(10.4 \mathrm{~m} / \mathrm{s})$ southerly wind along the path of air masses from Norilsk (Fig. 3). On the whole, the content of most chemical elements (Na, AI, K, Ca, Sc, Fe, $\mathrm{Co}, \mathrm{Rb}, \mathrm{Zr}$, Cs, Ba, rare-earth elements, Hf, Ta, $\mathrm{Th}$ and $\mathrm{U}$ ) in the insoluble fraction of the Arctic aerosols is lower than the mean value for the Earth's crust. In contrast, the content of $\mathrm{Cr}, \mathrm{Cu}$, $\mathrm{Zn}, \mathrm{As}, \mathrm{Se}, \mathrm{Br}, \mathrm{Ag}, \mathrm{Sb}$ and $\mathrm{Pb}$ is far higher than the mean value for the Earth's crust (Shevchenko et al., 2000).

In order to estimate the relative contribution from natural (e.g. rock and soil dust) vs. anthropogenic sources, the enrichment factors were calculated relative to the mean composition of the Earth's crust. For each element, the enrichment factor (EF) was calculated as

$$
\mathrm{EF}(\mathrm{El})=(\mathrm{El} / \mathrm{Sc}) \text { sample } /(\mathrm{El} / \mathrm{Sc}) \text { Earth's crust, }
$$

where $\mathrm{El}$ and $\mathrm{Sc}$ are the contents of the element of interest and Sc in the sample and in the Earth's crust (Taylor, 1964), respectively. Given the large variations in the composition of rocks and soils, enrichment factors within \pm 10 times the mean crustal abundance do not likely demonstrate the input from sources other than rock and soil dust. Marine sources did not contribute to the insoluble fraction of aerosols, because we washed out sea salt. So, very high values of EF of some heavy metals could be attributed to the anthropogenic 


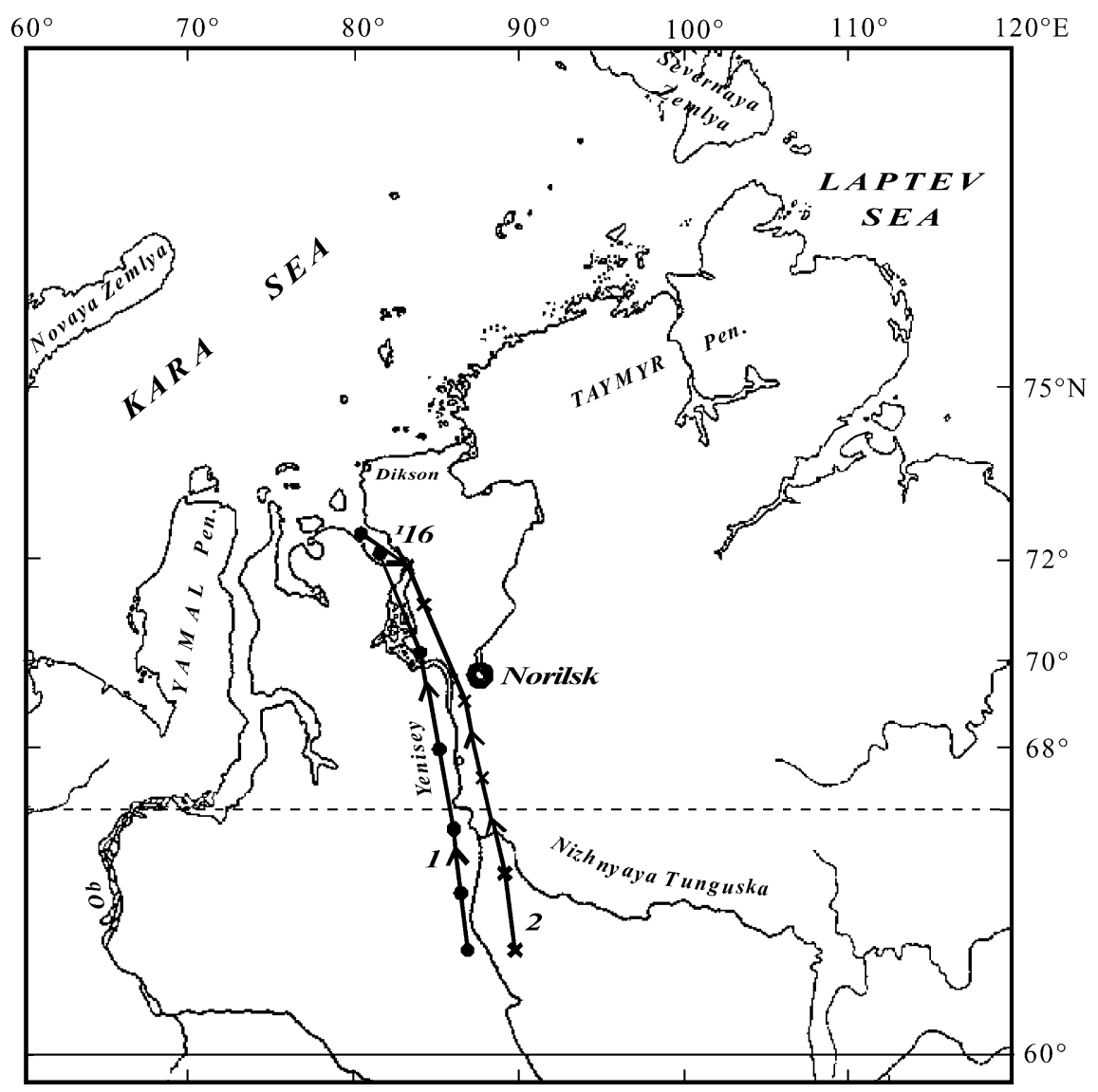

Fig. 3. Backward trajectories of air mass transport to the area of mesh sample number 16 in 49th expedition of the RV Dmitry Mendeleev (September 18, 1993) at isobaric surface of $1000 \mathrm{hPa}$ at $6 \mathrm{~h}$ intervals. Trajectories has been calculated for the point of beginning sampling (1) and the end of sampling (2).

source. For example, in the mesh samples of the SPASIBA-91 expedition (Shevchenko et al., 1999a), the analytes were divided into two groups in accordance with the EF value:

(1) the elements typical of the Earth's crust $(\mathrm{EF}<10), \mathrm{Na}, \mathrm{Mg}, \mathrm{Al}, \mathrm{K}, \mathrm{Ca}, \mathrm{Sc}, \mathrm{Mn}, \mathrm{Fe}, \mathrm{Co}, \mathrm{Ni}$, As, Rb, Cs, Ba, rare-earth elements, Hf, Ta, Th, $\mathrm{U}$; (2) the anthropogenic elements $(\mathrm{EF}>10), \mathrm{Cr}$, $\mathrm{Cu}, \mathrm{Zn}, \mathrm{Se}, \mathrm{Br}, \mathrm{Ag}, \mathrm{Cd}, \mathrm{Sb}, \mathrm{W}, \mathrm{Au}, \mathrm{Pb}$.

The highest enrichment factors for some elements, when compared to other samples, were calculated for sample number 16 taken from the 49th expedition of the RV Dmitrii Mendeleev $(\mathrm{EF}(\mathrm{Se})=22000, \mathrm{EF}(\mathrm{Ni})=418, \mathrm{EF}(\mathrm{Co})=69$ and $\mathrm{EF}(\mathrm{As})=43)$. The highest content of combustion spheres was also detected in the same sample. Their main source is anthropogenic, namely the Norilsk industrial region. The Norilsk MiningMetallurgical Plant is one of the world's largest plants for mining and processing of copper-nickel ore. This plant is one of the main sources of pollution in the north-eastern part of Russia emitting $\mathrm{S}, \mathrm{Se}, \mathrm{Cu}, \mathrm{Ni}, \mathrm{Co}, \mathrm{Sb}, \mathrm{As}, \mathrm{Pb}, \mathrm{Zn}$ and $\mathrm{Hg}$ into the atmosphere (Vilchek et al., 1996; AMAP, 1997).

\subsubsection{Elemental composition of aerosols (taking} into account sea salt; filtering method)

The elemental composition of aerosols as a whole was studied in the samples obtained by 
Table 2

Regions, times, numbers of samples and concentrations of Sc and heavy metals in aerosols in the Russian Arctic and some other areas (ng/ $\mathrm{m}^{3}$ )

\begin{tabular}{|c|c|c|c|c|c|c|c|c|c|c|c|c|c|c|c|}
\hline Region & Time & $N$ & $\mathrm{Sc}$ & $\mathrm{V}$ & $\mathrm{Cr}$ & $\mathrm{Mn}$ & $\mathrm{Fe}$ & Co & $\mathrm{Ni}$ & $\mathrm{Cu}$ & $\mathrm{Zn}$ & As & $\mathrm{Sb}$ & $\mathrm{Pb}$ & References \\
\hline Laptev Sea & $\begin{array}{l}\text { Summer } \\
1995\end{array}$ & 12 & 0.0081 & & 3.97 & & 142 & 0.102 & & & 15.4 & 0.38 & & & Shevchenko et al. (2000) \\
\hline Kara Sea & $\begin{array}{l}\text { September } \\
1993\end{array}$ & 14 & 0.00022 & & 0.044 & & 2.81 & 0.0041 & & & 1.58 & & 0.0032 & & Shevchenko et al. (1995) \\
\hline $\begin{array}{l}\text { St. Anna } \\
\text { Trough and } \\
\text { Barents Sea }\end{array}$ & $\begin{array}{l}\text { August- } \\
\text { October } \\
1994\end{array}$ & 10 & 0.0033 & & 5.66 & & 135 & 0.30 & 8.2 & & 43 & 0.15 & 0.064 & & Shevchenko et al. (1999c) \\
\hline $\begin{array}{l}\text { Norwegian } \\
\text { and } \\
\text { Greenland } \\
\text { Seas }\end{array}$ & $\begin{array}{l}\text { Summer } \\
1996\end{array}$ & 5 & 0.026 & & 0.665 & & 800 & & 19.1 & & 34.2 & 0.64 & 0.098 & & Shevchenko et al. (2000) \\
\hline Fram Strait & $\begin{array}{l}\text { Summer } \\
1997\end{array}$ & 8 & & & 0.56 & & 57 & & 11.1 & & 18.8 & 0.08 & 0.16 & & Shevchenko et al. (2000) \\
\hline Central Arctic & $\begin{array}{l}\text { Spring } \\
1987\end{array}$ & 15 & & 1.0 & 4.6 & 5.0 & 180 & & 2.2 & 7.0 & 14 & & & 13 & Vinogradova (1996) \\
\hline Central Arctic & $\begin{array}{l}\text { August- } \\
\text { October } \\
1991\end{array}$ & 7 & $<0.003$ & 0.043 & $<1.1$ & 0.26 & 10.6 & 0.019 & $<0.18$ & 0.16 & 0.18 & 0.022 & 0.019 & 0.2 & Maenhaut et al. (1996) \\
\hline Fram Strait & $\begin{array}{l}\text { August- } \\
\text { October } \\
1991\end{array}$ & 3 & $<0.004$ & 0.043 & $<1$ & 0.085 & 5.9 & 0.014 & $<0.2$ & $<0.15$ & 0.19 & $<0.06$ & $<0.005$ & 0.3 & Maenhaut et al. (1996) \\
\hline $\begin{array}{l}\text { Severnaya } \\
\text { Zemlya }\end{array}$ & $\begin{array}{l}\text { April- } \\
\text { May } \\
1985 \\
1986, \\
1988\end{array}$ & 22 & 0.014 & 0.75 & 1.6 & 1.4 & 31 & 0.075 & 6.1 & 3.8 & 5.8 & 1.8 & 0.19 & 3.5 & Vinogradova and Polissar (1995) \\
\hline Wrangel Island & $\begin{array}{l}\text { Springs } \\
1985-1989\end{array}$ & 52 & 0.11 & 0.86 & 4.5 & 3.8 & 160 & 0.49 & 8.1 & 6.4 & 16 & 0.8 & 0.19 & 10 & Vinogradova (1996) \\
\hline $\begin{array}{l}\text { Franz Josef } \\
\text { Land }\end{array}$ & $\begin{array}{l}\text { Spring } \\
1994\end{array}$ & 10 & & 0.7 & & 2.6 & 19 & & & 26 & 5.2 & & & 4.4 & Smirnov et al. (1998) \\
\hline $\begin{array}{l}\text { Spitsbergen, } \\
\text { Ni-Alesund }\end{array}$ & $\begin{array}{l}\text { Summer } \\
1984\end{array}$ & 13 & 0.0012 & 0.022 & 0.56 & 0.07 & 5.6 & $<0.004$ & $<0.2$ & $<0.3$ & $<0.15$ & 0.01 & 0.0024 & $<0.7$ & Maenhaut et al. (1989) \\
\hline $\begin{array}{l}\text { Spitsbergen, } \\
\text { Ni-Alesund }\end{array}$ & $\begin{array}{l}\text { Winter } \\
1983 \text {, } \\
1984 \\
\text { and } \\
1986\end{array}$ & 46 & 0.0043 & 0.54 & $<0.4$ & 0.77 & 17.8 & 0.0096 & 0.29 & $<0.9$ & 3.9 & 0.52 & 0.092 & 3 & Maenhaut et al. (1989) \\
\hline
\end{tabular}




\begin{tabular}{|c|c|c|c|c|c|c|c|c|c|c|c|c|c|c|c|}
\hline Region & Time & $N$ & Sc & $\mathrm{V}$ & $\mathrm{Cr}$ & $\mathrm{Mn}$ & $\mathrm{Fe}$ & Co & $\mathrm{Ni}$ & $\mathrm{Cu}$ & $\mathrm{Zn}$ & As & $\mathrm{Sb}$ & $\mathrm{Pb}$ & References \\
\hline $\begin{array}{l}\text { Canadian } \\
\text { Arctic, Alert }\end{array}$ & $\begin{array}{l}\text { March } \\
1985\end{array}$ & 12 & 0.01 & 0.295 & & 0.778 & 50 & 0.032 & & & 8.5 & 0.349 & 0.06 & & Landsberger et al. (1990) \\
\hline $\begin{array}{l}\text { Point } \\
\text { Barrow, } \\
\text { Alaska }\end{array}$ & $\begin{array}{l}\text { Spring } \\
1986\end{array}$ & 280 & & & & & 38 & & 4 & & 11 & & & & $\mathrm{Li}$ and Winchester (1990) \\
\hline $\begin{array}{l}\text { Greenland, } \\
\text { St. Summit }\end{array}$ & $\begin{array}{l}\text { Summer } \\
1990\end{array}$ & 29 & 0.003 & & & & 9.8 & 0.011 & & & 1.5 & 0.029 & & & Mosher et al. (1993) \\
\hline North Sea & $\begin{array}{l}1986- \\
1990\end{array}$ & 85 & & & & & & & & & 99 & 8 & 1.8 & & Dannecker et al. (1994) \\
\hline Black Sea & $\begin{array}{l}\text { June- } \\
\text { September } \\
1988\end{array}$ & 14 & 0.08 & & 9 & & 420 & 0.25 & 4.9 & & 46 & 1.1 & 0.6 & & Hacisalihoglu et al. (1992) \\
\hline Antarctic & & & 0.00016 & & 0.04 & & 0.62 & 0.0005 & & & 0.033 & & & & Maenhaut et al. (1979) \\
\hline
\end{tabular}


Table 3

Comparison of enrichment factors (EF) of aerosols sampled by nylon meshes or filtered in two expeditions (Shevchenko et al., 2000)

\begin{tabular}{|c|c|c|c|c|c|c|}
\hline \multirow[t]{2}{*}{ Method } & \multicolumn{6}{|c|}{ Element, mean (S.D.) } \\
\hline & $\mathrm{Na}$ & $\mathrm{Cr}$ & $\mathrm{Fe}$ & Co & $\mathrm{Ni}$ & $\mathrm{Zn}$ \\
\hline \multicolumn{7}{|c|}{ 49th expedition of the RV 'Dmitry Mendeleev', September, 1993} \\
\hline Meshes & $0.65(0.29)$ & $9.5(5.4)$ & $2.79(1.13)$ & $12(18)$ & - & $101(99)$ \\
\hline Filters Whatman 41 & $152(148)$ & $62(51)$ & $7.9(6.1)$ & $15(15)$ & $-(-)$ & $3550(3920)$ \\
\hline \multicolumn{7}{|c|}{ 9th expedition of the RV 'Professor Logachev', August-October, 1994} \\
\hline Meshes & $1.1(1.8)$ & $40(23)$ & $3.9(1.4)$ & $5.1(4.7)$ & $6.1(10.3)$ & $198(170)$ \\
\hline Filters AFA-KhA & 785 (1200) & $470(300)$ & $16(8)$ & $90(116)$ & $1320(2630)$ & $5060(3700)$ \\
\hline
\end{tabular}

filtering. In the case of filtering, the composition of particles larger than $0.5 \mu \mathrm{m}$, including (in contrast to the mesh samples) particles of sea salt, was examined.

The concentrations of aerosols in marine boundary layer in seas of the Russian Arctic vary widely both in space and in time (Vinogradova et al., 1993; Vinogradova and Polissar, 1995; Shevchenko et al., 1995, 1999c, 2000). Table 2 presents mean values of concentrations of Sc (crustal tracer) and heavy metals in aerosols in the Russian Arctic and in some other areas.

Shipboard studies of aerosols were carried out in summer and beginning of autumn. The variability of the aerosol element composition (from sample to sample) was very wide. This fact represents not only temporal, but also spatial variability of element concentrations, because the sites of sampling changed in accordance with the route of the vessel. Mean concentrations of most heavy metals in the atmosphere in the marine boundary layer in the Russian Arctic in summer are nearly of the same order as literature data from other Arctic areas (Table 2).

In Table 3, the mean values of enrichment factors (EF) of the aerosols sampled by Nylon mesh and by filtering are compared. For most elements the EF of the filtered samples is one to two orders of magnitude higher than that for the mesh samples. This proves that such elements are largely connected with sea-salt particles (washed from mesh by distilled water but preserved in filtration method) and submicron particles, which are not efficiently trapped by the mesh. The only exclusion is $\mathrm{Co}$, for which the mean values of the
$\mathrm{EF}$ are almost the same for the both sampling methods.

There are two main reasons of higher enrichment of total aerosol samples collected on filters in many chemical elements:

1. Sea-salt particles generated from the sea surface are enriched in many heavy metals due to fractionation in the surface microlayer (Duce et al., 1976; O'Dowd and Smith, 1993).

2. The concentrations of many microelements are higher in the finest $(<0.5 \mu \mathrm{m})$ fractions (Duce et al., 1976; Dulac et al., 1989). Such a small size range is often associated with emissions of high-temperature industrial processes (Brimblecombe, 1996) or with narrowing the aerosol size spectrum during long-range atmospheric transport (Barrie, 1986).

In the region of the St. Anna Trough and in the Barents Sea, in August 1994-October 1994 (Shevchenko et al., 1999c) the concentrations of almost all elements (except for bromine and copper) were higher than those given in Maenhaut et al. (1989) for Spitsbergen (at the distance of approx. $1 \mathrm{~km}$ from the shore). Moreover, our data exceed even spring values obtained in the period of maximum pollution of the Arctic atmosphere (Vinogradova and Polissar, 1995). Only concentrations of As, $\mathrm{Sb}$, as well as already mentioned $\mathrm{Br}$ and $\mathrm{Cu}$ in the Severnaya Zemlya were higher.

The significant enrichment of the aerosol with $\mathrm{Ni}$, in our opinion, is connected not only with its atmospheric transport from the regions of Norilsk and Kola Peninsula, but also with its fractionation at the sea surface (Duce et al., 1976). This is 
Table 4

Calculated 10-year averaged monthly mean concentrations for six anthropogenic chemical elements in the atmosphere at Franz Josef Land (FJL) and Severnaya Zemlya (SZ), and referenced measured data $\left(\mathrm{ng} \mathrm{m}^{-3}\right)$

\begin{tabular}{|c|c|c|c|c|c|c|c|}
\hline Point & Season & As & $\mathrm{Ni}$ & $\mathrm{Pb}$ & V & $\mathrm{Zn}$ & $\mathrm{Cd}$ \\
\hline \multirow[t]{4}{*}{ FJL } & Winter & 0.15 & 0.50 & 1.8 & 0.48 & 0.87 & 0.037 \\
\hline & Spring & 0.26 & 0.85 & 3.3 & 0.85 & 1.9 & 0.080 \\
\hline & Summer & 0.007 & 0.022 & 0.09 & 0.021 & 0.056 & 0.002 \\
\hline & Autumn & 0.0092 & 0.029 & 0.091 & 0.023 & 0.058 & 0.0027 \\
\hline FJL $^{a}$ & Spring & - & - & 44 & 0.7 & 5.2 & - \\
\hline \multirow[t]{4}{*}{ SZ } & Winter & 0.14 & 0.47 & 1.6 & 0.38 & 0.83 & 0.035 \\
\hline & Spring & 0.19 & 0.65 & 1.9 & 0.46 & 1.1 & 0.048 \\
\hline & Summer & 0.019 & 0.063 & 0.10 & 0.020 & 0.040 & 0.0026 \\
\hline & Autumn & 0.052 & 0.19 & 0.45 & 0.11 & 0.22 & 0.011 \\
\hline $\mathrm{SZ}^{\mathrm{b}}$ & Spring & $0.26-1.8$ & $1.1-11$ & 3.5 & $0.73-0.8$ & $0.6-13$ & 0.09 \\
\hline Spitsbergen $^{c}$ & Winter-spring & 0.52 & 0.29 & 3.0 & 0.54 & 3.9 & 0.080 \\
\hline Spitsbergen $^{\mathrm{d}}$ & Summer-autumn & 0.017 & $<0.14$ & $<1.0$ & 0.041 & 0.59 & $<0.06$ \\
\hline
\end{tabular}

${ }^{\text {a }}$ Smirnov et al. (1998)_March, 1994.

b Vinogradova and Polissar (1995)—1985, 1986 and 1988.

${ }^{\mathrm{c}}$ Maenhaut et al. (1989)—1983, 1984 and 1986.

${ }^{\mathrm{d}}$ Cornille (1991)—1984, 1986 and 1987.

indicated by high coefficients of correlation between concentrations of $\mathrm{Ni}$ and $\mathrm{Na}$.

Aerosol studies at the Severnaya Zemlya Archipelago and at Wrangel Island in spring 1985-1989 revealed that mean concentrations of most heavy metals (Table 2) and their enrichment factors were similar to characteristics of aerosol in spring from other Arctic regions and higher than summer values at Spitsbergen (Maenhaut et al., 1989). The origin of some individual samples of aerosols was identified by the method of Rahn and Lowenthal (1984) applying the ratios of element-tracer concentrations. Air transport of pollutants from Europe, Kola Peninsula, and North America have been registered. Factor analysis of concentration data obtained in 1985 and 1988 divided the 10 elements into four groups: soil ( $\mathrm{Fe}, \mathrm{Al}, \mathrm{Mn})$; marine $(\mathrm{Na}, \mathrm{Cl}, \mathrm{Br})$; and two of anthropogenic origin which sources may be coal and fuel combustion ( $\mathrm{Sb}, \mathrm{Co}$ ); or non-ferrous metal-smelter industry (Sb, Zn) (Vinogradova et al., 1993).

\subsection{Long-range pollutant transport into the Rus- sian Arctic (10-year average characteristics)}

We investigated long-term features of longrange transport of air masses and conservative anthropogenic pollutants in and out of the Russian Arctic using the synoptical data collected over a 10 -year period. We were interested in finding the most significant sources and sinks of anthropogenic contaminants in the Arctic atmosphere in different seasons.

Three points in the Russian Arctic-at Franz Josef Land (FJL) $-81.1^{\circ} \mathrm{N}, 56.3^{\circ} \mathrm{E}$; at archipelago Severnaya Zemlya (SZ) $-79.5^{\circ} \mathrm{N}, 95.4^{\circ} \mathrm{E}$; at the Wrangel Island (WI) $-71.0^{\circ} \mathrm{N}, 178.5^{\circ} \mathrm{W}$-were chosen as observation points. We analyzed daily 5day forward and backward trajectories of air mass transport for January, April, July and October of 1986-1995 for each point. The trajectories were calculated in $6 \mathrm{~h}$ intervals at isobaric surfaces of 925 and $850 \mathrm{hPa}$ applying the software created in the Russian Hydrometeocenter and adapted to their meteorological and synoptical database. As remarked by Kahl (1993), the uncertainties in calculating each trajectory become stochastic when observed on a large set of trajectories. We assumed that trajectories at those two levels are representative of the general direction of air mass pathways under investigation, and statistically analyzed approximately 600 trajectories in 'double' set (for each point and each month). 
Table 5

The main industrial sources of six chemical elements in the atmosphere at Franz Josef Land and Severnaya Zemlya in different seasons; contributions (in \% from the average element concentration) are in brackets

\begin{tabular}{|c|c|c|c|c|c|}
\hline \multirow[t]{2}{*}{ Point } & \multirow[t]{2}{*}{ Season } & \multirow{2}{*}{$\begin{array}{l}\text { Arctic air } \\
\text { for all the } \\
\text { elements }\end{array}$} & \multicolumn{3}{|l|}{ For the elements: } \\
\hline & & & As, Ni & $\mathrm{Pb}, \mathrm{V}$ & $\mathrm{Zn}, \mathrm{Cd}$ \\
\hline Franz & Winter & (38) & $\begin{array}{l}\text { Kola Penin. (16) } \\
\text { The Urals (15) } \\
\text { Norilsk (15) }\end{array}$ & $\begin{array}{l}\text { The Urals (22) } \\
\text { N. Europe (16) }\end{array}$ & $\begin{array}{l}\text { N. Europe (22) } \\
\text { The Urals (18) }\end{array}$ \\
\hline Josef & Spring & (46) & $\begin{array}{l}\text { N. Europe (16) } \\
\text { Kola Penin. (15) } \\
\text { Norilsk (11) }\end{array}$ & $\begin{array}{l}\text { N. Europe }(30) \\
\text { The Urals }(11)\end{array}$ & $\begin{array}{l}\text { N. Europe }(30) \\
\text { Kola Penin. }(10)\end{array}$ \\
\hline \multirow[t]{2}{*}{ Land } & Summer & $(<0.5)$ & $\begin{array}{l}\text { Kola Penin. (45) } \\
\text { N. Europe (36) } \\
\text { Norilsk (12) }\end{array}$ & $\begin{array}{l}\text { N. Europe (76) } \\
\text { Kola Penin. (11) }\end{array}$ & $\begin{array}{l}\text { N. Europe (81) } \\
\text { Kola Penin. (12) }\end{array}$ \\
\hline & Autumn & $(<3)$ & $\begin{array}{l}\text { Kola Penin. (50) } \\
\text { N. Europe (14) } \\
\text { CESU* (10) } \\
\text { Norilsk (9) }\end{array}$ & $\begin{array}{l}\text { N. Europe (38) } \\
\text { Kola Penin. (17) } \\
\text { C. Europe (14) } \\
\text { The Urals (13) } \\
\text { W. Europe (10) }\end{array}$ & $\begin{array}{l}\text { N. Europe (37) } \\
\text { Kola Penin. (17) } \\
\text { C. Europe (15) } \\
\text { W. Europe (10) } \\
\text { Kuznetsk reg. (9) }\end{array}$ \\
\hline Severnaya & Winter & (40) & $\begin{array}{l}\text { Norilsk (25) } \\
\text { The Urals (12) } \\
\text { Kola Penin. (11) }\end{array}$ & $\begin{array}{l}\text { the Urals }(23) \\
\text { N. Europe }(10) \\
\text { CESU }^{a}(8)\end{array}$ & $\begin{array}{l}\text { the Urals (15) } \\
\text { Kuznetsk reg. (14) } \\
\text { N. Europe (11) }\end{array}$ \\
\hline \multirow[t]{2}{*}{ Zemlya } & Spring & (52) & $\begin{array}{l}\text { Norilsk (22) } \\
\text { Kola Penin. (9) }\end{array}$ & $\begin{array}{l}\text { N. Europe (18) } \\
\text { The Urals (13) }\end{array}$ & $\begin{array}{l}\text { N. Europe (20) } \\
\text { The Urals (8) } \\
\text { Kuznetsk reg. (8) }\end{array}$ \\
\hline & Summer & $(<0.5)$ & $\begin{array}{l}\text { Norilsk (57) } \\
\text { Kola Penin. (18) }\end{array}$ & $\begin{array}{l}\text { Norilsk (51) } \\
\text { The Urals (15) } \\
\text { N. Europe (13) } \\
\text { Kola Penin. (9) } \\
\text { the Urals (22) } \\
\text { N. Europe (20) } \\
\text { Norilsk (17) } \\
\text { W. Europe (16) }\end{array}$ & $\begin{array}{l}\text { Norilsk (58) } \\
\text { N. Europe (21) } \\
\text { The Urals (9) } \\
\text { Kola Penin. (9) } \\
\text { N. Europe (23) } \\
\text { Norilsk (21) } \\
\text { W. Europe (18) } \\
\text { The Urals (14) }\end{array}$ \\
\hline
\end{tabular}

${ }^{\mathrm{a}}$ CESU - center of European part of the former Soviet Union.

The method of trajectory classification, and model calculation were described by Vinogradova (Vinogradova and Yegorov, 1996, 1997; Vinogradova, 2000; Vinogradova and Ponomareva, 2001). We used the Pacyna's data for Eurasian industrial source-region emissions from (Pacyna et al., 1984, 1985) with the data corrections for 1990 from Pacyna (1998).

Average monthly (10-year) mean concentrations of six elements of primary anthropogenic origin in atmosphere (As, Ni, Pb, V, Zn and $\mathrm{Cd}$ ) at Franz Josef Land and Severnaya Zemlya are represented in Table 4. Average contributions from industrial regions to the Russian Arctic atmospheric pollution in different seasons were estimated for these six elements. They vary not only proportionally to source emissions, but also depend on the efficiency of atmospheric pollution transport to an observation point. The most polluting source may not be the one with the highest emission level, and is determined by both the observation point location and the contaminant (Table 5). Industrial areas of North Europe, Kola Peninsula, Urals and Norilsk region are the main sources of atmospheric heavy metals in the Russian Arctic. The North American pollution sources play a major role only in the 


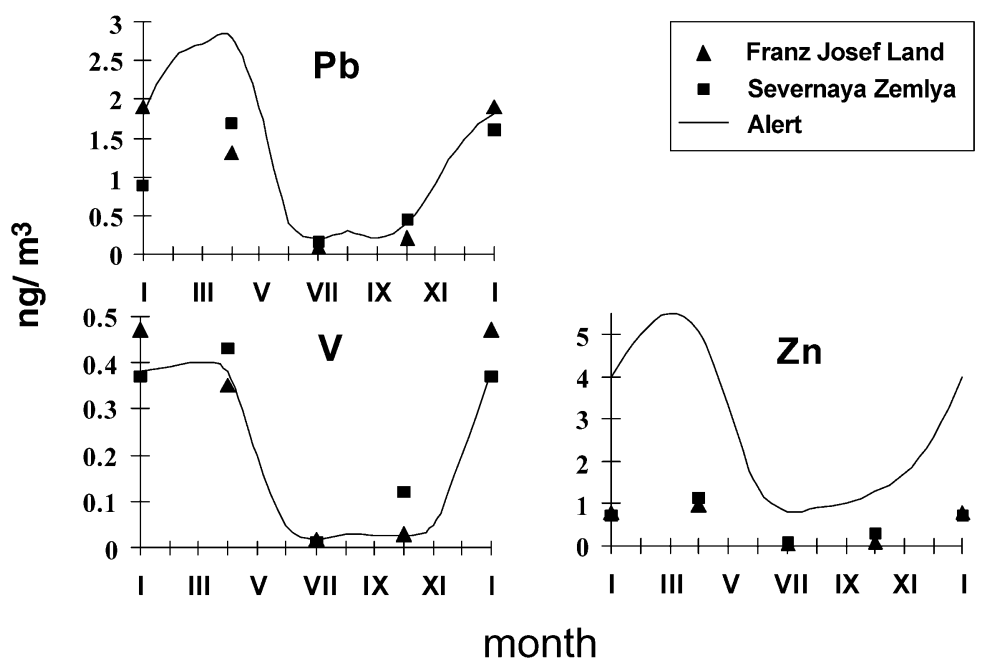

Fig. 4. Seasonal variations in 10-year averaged atmospheric concentrations of Pb, V, Zn at Franz Josef Land and Severnaya Zemlya with 15-year averaged experimental data for Alert, Canada (Sirois and Barrie, 1999).

eastern part of the Russian Arctic. Because emission data for the chemical elements under investigation for North American sources were incomplete, estimates of source contributions to air pollution at Wrangel Island (where the role of North American source-regions is maximal (Vinogradova, 2000) were not carried out. In winter and spring, up to $50 \%$ of an air pollutant average concentration in the Russian Arctic are due to the Arctic atmospheric pollution itself.

There was reasonable correspondence between 10-year averaged calculated elemental concentrations for Russian Arctic and 15-year averaged experimentally measured ones was obtained during 1 year (Fig. 4). Differences for $\mathrm{Zn}$ may be explained by underestimating its emission or by a large contribution from natural sources to its concentration.

The atmospheric pollution transport from the Arctic (to the south from the $70^{\circ} \mathrm{N}$ ) was also considered as yet another way of cleaning the Arctic atmosphere (inside the $70^{\circ} \mathrm{N}$ ), in addition to the traditionally considered wet and dry deposition onto the surface. Keeping in mind, the monthly and annual averaged fluxes of six anthropogenic chemical elements onto the surface in the Arctic have been estimated, and the values obtained are in reasonable agreement with the literature data available (Table 6). Note that our estimates concern only the anthropogenic portion of elemental concentrations and depositions.

\section{Conclusions}

Concentrations of most heavy metals in the atmosphere in the marine boundary layer in the Russian Arctic are nearly of the same order as literature data from other Arctic areas. In summer/ autumn period increased concentrations of heavy metals in most cases could be explained by natural processes (generation of sea salt aerosols, etc.). Temporal and spatial variations of heavy metal concentration in the marine arctic atmosphere are caused both by changing intensity of sea-salt particle generation and by air mass transport to the observation points. In some cases air transport of aerosols from Norilsk, Kola Peninsula, Europe, and North America has been identified.

The content of heavy metals in aerosols over the seas of the Russian Arctic showed an annual variation with maximal concentrations of anthropogenic components during the winter/spring season. Averaged over 10 years, in winter and spring, up to $50 \%$ of the air pollutant concentrations in the Russian Arctic are due to the Arctic atmospheric pollution itself. 
Table 6

Monthly and annual deposition on the surface in the Arctic for six chemical elements based on the estimated anthropogenic part of their concentrations (averaged for Franz Josef Land and Severnaya Zemlya)

\begin{tabular}{|c|c|c|c|c|c|c|}
\hline Season & As & $\mathrm{Ni}$ & $\mathrm{Pb}$ & $\mathrm{V}$ & $\mathrm{Zn}$ & $\mathrm{Cd}$ \\
\hline \multicolumn{7}{|c|}{ Monthly fluxes, $\mu \mathrm{g} \mathrm{m}^{-2}$ month $^{-1}\left(\mathrm{~g} \mathrm{~km}^{-2}\right.$ month $\left.^{-1}\right)$} \\
\hline Winter & 0.22 & 0.74 & 2.7 & 0.71 & 1.3 & 0.056 \\
\hline Spring & 0.27 & 0.90 & 2.8 & 0.73 & 1.9 & 0.065 \\
\hline Summer & 0.049 & 0.19 & 0.58 & 0.15 & 0.35 & 0.015 \\
\hline Autumn & 0.15 & 0.47 & 1.1 & 0.28 & 0.54 & 0.026 \\
\hline Spring* & 0.7 & 2.3 & 1.0 & 1.1 & 5.8 & 0.06 \\
\hline \multicolumn{7}{|c|}{ Annual fluxes, $\mu \mathrm{g} \mathrm{m}^{-2}$ year $^{-1}\left(\mathrm{~g} \mathrm{~km}^{-2}\right.$ year $\left.^{-1}\right)$} \\
\hline Annual & 2.1 & 7.0 & 23 & 6.0 & 12 & 0.51 \\
\hline ** & - & 65 & 60 & - & - & 1.5 \\
\hline
\end{tabular}

Annual depositions on the Arctic Ocean $\left(1.2 \times 10^{13} \mathrm{~m}^{2}\right)$, tons year $^{-1}$

$\begin{array}{lcccccc}\text { Annual } & 25 & 90 & 280 & 72 & 150 & 6.5 \\ * * * * & - & - & 150 & 59 & - & 3.9\end{array}$

\footnotetext{
* Based on experimental atmospheric concentration data of Vinogradova (1996) at Wrangel Island in 1985-1989.

** Based on snow precipitation composition data in North Atlantic (Mart, 1983).

${ }^{* * *}$ Estimates of Akeredolu et al. (1994) from model calculations of heavy metal concentrations in the Arctic atmosphere in 1979-1980.
}

Four industrial areas (North Europe, Kola Peninsula, Ural, and Norilsk region) were the main sources of atmospheric heavy metals in the Russian Arctic in 1986-1995. The North American pollution sources played a significant role only in the eastern part of the Russian Arctic (particularly, at Wrangel Island).

Ten year averaged monthly and annual mean concentrations of $\mathrm{As}, \mathrm{Ni}, \mathrm{Pb}, \mathrm{V}, \mathrm{Zn}, \mathrm{Cd}$ and their fluxes onto the surface in the Arctic have been estimated, and the values obtained are in reasonable agreement with the literature data available.

For more progress in our understanding the sources, pathways and fluxes of heavy metals and other pollutants in the Arctic marine environment it is necessary to establish monitoring stations in key areas of the Russian Arctic.

\section{Acknowledgments}

The authors are thankful to the crews of the research vessels Yakov Smirnitskii, Dmitrii Men- deleev, Professor Logachev, Akademik Mstislav Keldysh, Akademik Sergei Vavilov, Akademik Fyodorov, Polarstern for the help during the research cruises. The authors are indebted to the colleagues who took part in joint studies of aerosols in the Arctic seas: U. Bock, A.A. Burovkin, L.V. Demina, N.I. Golubeva, A.B. Isaeva, G.l. Ivanov, A.A. Klyuvitkin, G. Kuhn, V.M. Kuptsov, V.N. Lukashin, A.N. Novigatsky, N.V. Politova, T.Ya. Ponomareva, V.Yu. Rusakov, V.V. Serova, O.V. Severina, V.V. Smirnov, R. Van Grieken, A.I. Voskresensky. The authors are thankful to I.V. Sadovnikova for the graphics. We would like to express our gratitude to Academician V.E. Zuev for his recommendations. This work was partially supported by the Russian Foundation for Basic Research (grant nos. 96-05-00043 and 00-1598623), German Scientific Research Society (grant DFG STE-412/10-2), the Ministry of Science of the Russian Federation (grant 'Global changes of the environment and climate. Direction no. 1'), and by Otto Schmidt Laboratory in the frame of 'Laptev Sea 2000' project.

\section{References}

Akeredolu FA, Barrie LA, Olson MP, Oikawa KK, Pacyna JM, Keeler GJ. The flux of anthropogenic trace metals into the Arctic from the mid-latitudes in 1979/80. Atmos Environ 1994;28:1557-1572.

AMAP. Arctic pollution issues: a state of the arctic environment report. Oslo: AMAP (Arctic Monitoring and Assessment Programme), 1997. (188 p).

Barrie LA. Arctic air pollution: an overview of current knowledge. Atmos Environ 1986;20:643-663.

Barrie LA. Occurrences and trends of pollution in the Arctic troposphere. In: Wolff EW, Bales RC, editors. Chemical exchange between the atmosphere and polar snow. BerlinHeidelberg: Springer-Verlag, 1996. p. 93-129.

Bigg EK, Leck C. Properties of the aerosol over the central Arctic Ocean. J Geophys Res 2001;106:32101-32110.

Brimblecombe P. Air composition and chemistry. Cambridge University Press, 1996. (253 p).

Chester R, Johnson LR. Atmospheric dust collected off the West African coast. Nature 1971;229:105-107.

Cornille P. Chemische karakterisering en brononderzoek van het atmosferisch aerosol. Ph.D. Thesis. Belgium: University of Gent, 1991. [in Dutch].

Dannecker W, Hinzpeter H, Kirzel H-J, Luthardt H, Kriews M, Naumann K, Schulz M, Schwikowski-Gigar M, Steiger M, Terzenbach U. Atmospheric transport of contaminants, their ambient concentration and input into the North Sea. 
In: Sundermann J, editor. Circulation and contaminant fluxes in the North Sea. Berlin: Springer-Verlag, 1994. p. 138189.

Duce RA, Hoffman GL, Ray BJ, Fletcher IS, Wallace GT, Fasching JL, Piotrowicz SR, Walsh PR, Hoffman EJ, Miller JM, Heffter JL. Trace metals in the marine atmosphere: sources and fluxes. In: Windom HL, Duce RA, editors. Marine pollutant transfer. Toronto: Lexington Books, 1976. p. $77-119$.

Duce RA, Liss PS, Merrill JT, Atlas EL, Buat-Menard P, Hicks BB, Miller JM, Prospero JM, Arimoto R, Church TM, Ellis W, Galloway JN, Hansen L, Jickells TD, Knap AH, Reinhardt KH, Schneider B, Soudine A, Tokos JJ, Tsunogai S, Wollast R, Zhou M. The atmospheric input of trace species to the World ocean. Global Biogeochem Cycles 1991;5:193259.

Dulac F, Buat-Menard P, Ezat U, Melki S, Bergametti G. Atmosperic input of trace metals to the western Mediterranean: uncertainties in modelling dry deposition from cascade impactor data. Tellus 1989;41B:362-378.

Golubeva NI, Shevchenko VP. To the question of the atmospheric aerosol composition in the Arctic. Abstracts of XIII International Conference on Marine Geology, Moscow, vol. 1 1999. p. 222-223.

Hacisalihoglu G, Eliyakut F, Olmez I, Balkas TI, Tuncel G. Chemical composition of particles in the Black Sea atmosphere. Atmos Environ 1992;26A:3207-3218.

Kahl JD. A cautionary note on the use of air trajectories in interpreting atmospheric chemistry measurements. Atmos Environ 1993;27A:3037-3038.

Koutsenogii KP, Kovalskaya GA, Smirnova AI. A study of the multielemental composition of atmospheric aerosols of Siberia by the SRXRF method. Nucl Instrum Methods Phys Res A 2000;448:434-437.

Koutsenogii PK, Boufetov NS, Smirnova AI, Koutsenogii KP. Elemental composition of atmospheric aerosols in Siberia. Nucl Instrum Methods Phys Res A 1998;405:546-549.

Landsberger S, Vermette SJ, Barrie LA. Multielemental composition of the Arctic aerosols. J Geophys Res 1990;95:3509-3513.

Leck C, Bigg EK, Covert DS, Heintzenberg J, Maenhaut W, Nilsson ED, Wiedensohler A. Overview of the atmospheric research program during the International Arctic Ocean Expedition of 1991 (IAOE-91) and its scientific results. Tellus 1996;48B:136-155.

Leinen M, Prospero JM, Arnold E, Blank M. Mineralogy of aeolian dust reaching the North Pacific Ocean. 1. Sampling and analysis. J Geophys Res 1994;99:21017-21023.

Li SM, Winchester JM. Haze and other aerosol components in late winter Arctic Alaska, 1986. J Geophys Res 1990;95:1797-1810.

Lisitzin AP. Oceanic sedimentation. Lithology and geochemistry. Washington, DC: American Geophysical Union, 1996. (400 p).

Macdonald RW, Barrie LA, Bidleman TF, Diamond ML, Gregor DJ, Semkin RG, Strachan WMJ, Li YF, Wania F,
Alaee M, Alexeeva LB, Backus SM, Bailey R, Bewers JM, Gobeil C, Halsall CJ, Harner T, Hoff JT, Jantunen LMM, Lockhart WL, Mackay D, Muir DCG, Pudykiewicz J, Reimer KJ, Smith JN, Stern GA, Schroeder WH, Wagemann R, Yunker MV. Contaminants in the Canadian Arctic: 5 years of progress in understanding sources, occurrence and pathways. Sci Total Environ 2000;245:93-234.

Maenhaut W, Cornille P, Pacyna JM, Vitols V. Trace element composition and origin of the atmospheric aerosol in the Norwegian Arctic. Atmos Environ 1989;23:2551-2569.

Maenhaut W, Zoller WH, Duce RA, Hoffman GL. Concentration size distribution of particulate trace elements in the south Polar atmosphere. J Geophys Res 1979;84:24212431.

Maenhaut W, Ducastel G, Leck C, Nilsson ED, Heintzenberg J. Multielemental composition and sources of the high Arctic atmospheric aerosol during summer and autumn. Tellus 1996;48B:300-321.

Mart L. Seasonal variations of $\mathrm{Cd}, \mathrm{Pb}, \mathrm{Cu}$ and $\mathrm{Ni}$ levels in snow from the eastern Arctic Ocean. Tellus 1983;35B:131141.

Mosher BW, Winkler P, Jaffrezo JL. Seasonal aerosol chemistry at Dye 3, Greenland. Atmos Environ 1993;27A:2761 2772.

O'Dowd CD, Smith MH. Physicochemical properties of aerosols over the Northeast Atlantic: Evidence for wind-speedrelated submicron sea-salt aerosol production. J Geophys Res 1993;98:1137-1149.

Pacyna JM. Chemical tracers of the origins of arctic air pollution. In: Sturges WT, editor. Pollution of the Arctic atmosphere. London and New York: Elsevier, 1991. p. 97122.

Pacyna JM. Source inventories for atmospheric trace metals. In: Harrison RM, Van Grieken R, editors. Atmospheric particles. Chichester: Wiley, 1998. p. 385-423.

Pacyna JM, Ottar B, Tomza U, Maenhaut W. Long-range transport of trace elements to Ny-Alesund, Spitsbergen. Atmos Environ 1985;19:857-864.

Pacyna JM, Semb A, Hanssen JE. Emission and long-range transport of trace elements in Europe. Tellus 1984;36B:163178.

Pfirman SL, Eicken H, Bauch D, Weeks WF. The potential transport of pollutants by Arctic sea ice. Sci Total Environ 1995;159:129-146.

Rahn KA. Atmospheric, riverine and oceanic sources of seven trace constituents to the Arctic ocean. Atmos Environ 1981;15:1507-1516.

Rahn KA, Lowenthal DH. Elemental tracers of distant regional pollution aerosols. Science 1984;223:132-139.

Rovinsky F, Pastukhov B, Bouyolov Y, Burtseva L. Present day state of background pollution of the natural environment in the Russian Arctic in the region of the Ust-Lena Reserve. Sci Total Environ 1995;160/161:193-199.

Shevchenko VP, Lisitzin AP, Kuptzov VM, Ivanov GI, Lukashin VN, Martin JM, Rusakov VY, Van Grieken R, 
Van Malderen H. Composition of aerosols over the Laptev, Kara, Barents, Greenland and Norwegian seas. Ber Polarforschung 1995;176:7-16.

Shevchenko VP, Lisitzin AP, Kuptzov VM, Van Malderen H, Martin JM, Van Grieken R, Huang WW. Composition of aerosols in the surface boundary layer of the atmosphere over the seas of the western Russian Arctic. Oceanology 1999a;39:128-136. [English translation].

Shevchenko VP, Lisitzin AP, Stein R, Serova VV, Isaeva AB, Politova NV. The composition of the coarse fraction of aerosols in the marine boundary layer over the Laptev, Kara and Barents Seas. In: Kassens H, Bauch HA, Dmitrenko IA, Eicken H, Hubberten H-W, Melles M, Thiede J, Timokhov IA, editors. Land-ocean systems in the Siberian Arctic: dynamics and history. Berlin: Springer-Verlag, 1999b. p. 53-58.

Shevchenko VP, Vinogradova AA, Ivanov GI, Lisitzin AP, Serova VV. The composition of aerosols in the marine boundary layer over the St. Anna Trough and the Barents Sea. Ber Polarforschung 1999c;342:15-26.

Shevchenko VP, Lisitzin AP, Vinogradova AA, Smirnov VV, Serova VV, Stein R. Arctic aerosols. Results of ten-year investigations. Atmos Oceanic Opt 2000;13:510-533.

Sirois A, Barrie LA. Arctic lower tropospheric aerosol trends and composition at Alert, Canada: 1980-1995. J Geophys Res 1999;104:11599-11618.

Smakhtin LA, Filippova NV, Shokel ES. The use of universal comparator method in large-scale INAA. J Radioanal Nucl Chem Lett 1991;155:1-8.

Smirnov VV, Radionov VF, Savchenko AV, Pronin AA, Kuusk VV. Variability in aerosol and air ion composition in the Arctic spring atmosphere. Atmos Res 1998;49:163-176.
Taylor SR. The abundance of chemical elements in the continental crust-a new table. Geochem Cosmochem Acta 1964;28:1273-1285.

Vilchek GE, Krasovskaya TM, Tsyban AV, Chelyukanov VV. The environment in the Russian Arctic: status report. Polar Geogr 1996;20:20-43.

Vinogradova AA. Elemental composition of atmospheric aerosol in eastern Arctic regions. Izv Atmos Oceanic Phys 1996;32:440-447.

Vinogradova AA. Anthropogenic pollutants in the Russian Arctic atmosphere: sources and sinks in spring and summer. Atmos Environ 2000;34:5151-5160.

Vinogradova AA, Malkov IP, Nazarov BI, Polissar AV. Determination of paths by which anthropogenic aerosol is transported into the Arctic. Izv Atmos Oceanic Phys 1988;24:497-502.

Vinogradova AA, Malkov IP, Polissar AV, Khramov NN. Elemental composition of the surface atmospheric aerosol in the Arctic regions of Russia. Izv Atmos Oceanic Phys 1993;29:149-157.

Vinogradova AA, Polissar AV. Elemental composition of the aerosol in the atmosphere of the central Russian Arctic. Izv Atmos Oceanic Phys 1995;31:248-257.

Vinogradova AA, Ponomareva TYa. Seasonal variations in the concentrations and precipitation of anthropogenic pollutants in the Russian Arctic atmosphere. Izv Atmos Ocean Phys 2001;37:761-770.

Vinogradova AA, Yegorov VA. Long-range pollutant transport into the Russian Arctic. Izv Atmos Oceanic Phys 1996;32:731-737.

Vinogradova AA, Yegorov VA. Contributions of industrial areas of the Northern hemisphere to air pollution in the Russian Arctic. Izv Atmos Oceanic Phys 1997;33:695-701. 